\title{
ТЕРАПІЯ
}

https://doi.org/10.35339/msz.2019.82.01.04

УДК 616.441-002:616.12-008.46.001.572

\section{С.М. Пивовар}

ДУ «Національний інститут терапії ім. Л.Т. Малої НАМН Украӥни», м. Харків

\section{МОДЕЛЬ НЕСПРИЯТЛИВОГО ПЕРЕБІГУ СЕРЦЕВОЇ НЕДОСТАТНОСТІ 3 УРАХУВАННЯМ ТИРЕОЇДНОГО СТАТУСУ ХВОРИХ}

\begin{abstract}
Обстежено 157 пацієнтів із серцевою недостатністю $(\mathrm{CH})$ - перенесеним інфарктом міокарда, у яких визначали предиктори несприятливого перебігу захворювання залежно від тиреоїдного статусу. При госпіталізації проведено стандартизоване оцінювання стану, визначено показники внутрішньосерцевої гемодинаміки, клінічного й біохімічного аналізів крові, рівні гормонів щитоподібної залози. Установлено, що ризик повторної госпіталізації хворих на СН із приводу декомпенсації захворювання зростає за перевищення оптимальної точки поділу для сироваткового рівня вільного трийодтироніну $\leq 2,07$ пмоль/л. Відносний ризик повторної госпіталізації хворих із СН протягом 2 років при рівні вільного трийодтироніну $\leq 2,07$ пмоль/л становить 2,224 [1,363-3,630] (p<0,05). За допомогою автоматичного регресійного аналізу побудовано модель повторної госпіталізації пацієнтів із СН у зв'язку з декомпенсацією захворювання протягом 2 років. До неї ввійшли такі показники: маса тіла, рівень вільного трийодтироніну, наявність нетоксичного зобу, рівні холестерину ліпопротеїдів низької щільності й загального холестерину, відносний вміст гранулоцитів у крові, концентрація вільного тироксину. За даними ROC-аналізу, ризик розвитку повторної госпіталізації хворих із СН у зв'язку з декомпенсацією захворювання зростає при перевищенні оптимальної точки поділу для значення рівняння регресійної моделі $\geq 1,321$ ум. од. У зв'язку з тим що зниження сироваткового рівня трийодтироніну впливає на перебіг $\mathrm{CH}$, можна припустити доцільним використання його значення $\leq 2,07$ пмоль/л як предиктора несприятливого перебігу захворювання.

Ключові слова: серчева недостатність, трийодтиронін, тироксин, перебіг захворювання, регресійна модель.
\end{abstract}

\section{Вступ}

Концепція щодо важливої ролі дисфункції щитоподібної залози у прогресуванні серцевої недостатності $(\mathrm{CH})$ підтримується даними п'яти клінічних досліджень [1-5]. У останніх продемонстровано, що зниження рівня трийодтироніну $\left(\mathrm{T}_{3}\right)$ за нормальних рівнів тироксину $\left(\mathrm{T}_{4}\right)$ та тиреотропного гормону (ТТГ) $\epsilon$ не похідним інших, більш потужних параметрів, таких, наприклад, як фракція викиду лівого шлуночка (ЛШ), а незалежним прогностичним маркером. У епоху економічної ефективності й високих технологій варто шукати доступні й недорогі інструменти, що можуть полегшити діагностику та / або прийняття тактичного рішення. Такими маркерами можуть бути сироваткові рівні $\mathrm{T}_{3}, \mathrm{~T}_{4}$ та ТТГ. Ïх визначають у рутинній клінічній практиці та легко інтерпретують на відміну від більшості відомих біогуморальних факторів [6].

Мета даної роботи - визначити предиктори несприятливого перебігу серцевої недостатності з урахуванням тиреоїдного статусу хворих.

(C) C.M. Пивовар, 2019 


\section{Матеріал і методи}

До дослідження включено 157 хворих із СН (36 жінок і 121 чоловіка) європеоїдної раси (основна група). Критеріями включення були: підписання інформованої згоди, перенесений інфаркт міокарда в анамнезі, верифікований діагноз CH I-IV функціональних класів за NYHA. Критерії виключення такі: непідписання інформованої згоди; гемодинамічно значущі клапанні вади серця; $\mathrm{CH}$ іншої за післяінфарктний кардіосклероз етіології; замісна гормональна терапія L-тироксином; тиреосупресивна терапія; клінічний чи субклінічний гіпотиреоз; тиреотоксикоз; запальні захворювання; інші серйозні патології (пухлина, туберкульоз), що могли б ускладнити лікування чи знизити очікувану тривалість життя.

До контрольної групи ввійшли 17 здорових осіб європеоїдної раси, порівнянних за віком і співвідношенням статі з пацієнтами основної групи.

Діагностування СН і лікування хворих проводили відповідно до рекомендацій Свропейського товариства кардіологів [7]. Пацієнти при госпіталізації пройшли стандартизоване оцінювання, що полягало в детальному вивченні історії хвороби (супутніх захворювань та терапії), фізикальному огляді, клінічному та біохімічному аналізах крові, електрокардіограмі (12 відведень).

Допплер-ехокардіоскопічне дослідження проводили за допомогою ультразвукової діагностичної системи VIVID-3 (General Electric, США). Визначали кінцево-діастолічний та кінцево-систолічний розміри ЛШ, товщину міжшлуночкової перегородки та задньої стінки ЛШ, діаметр лівого передсердя, правого шлуночка та інші показники. Розраховували кінцево-діастолічний і кінцево-систолічний об'єми ЛШ, фракцію викиду ЛШ, індекс лівого передсердя, масу міокарда ЛШ та іiї індекс.

Дослідження зразків крові проводили в лабораторії біохімічних та імуноферментних методів досліджень із морфологією. Для визначення сироваткового рівня тиреотропного гормону (ТТГ, діапазон норми - 0,3-4,0 мМО/л), вільного $\mathrm{T}_{3}\left(\mathrm{~T}_{3 \mathrm{~B}}\right.$, діапазон норми $-2,5-5,8$ пмоль/л) та вільного $\mathrm{T}_{4}\left(\mathrm{~T}_{4 \mathrm{~B}}\right.$, діапазон норми - $10-25$ пмоль/л) використовували набори реактивів «ТТГ-ІФА», «вТ4-ІФА» та «вТ3-ІФА» (компанія «Хема», Україна). Рівень реверсивного трийодтироніну $\left(\mathrm{T}_{3 \mathrm{r}}\right.$, діапазон норми -90-350 пг/мл) визначали за допомогою реактиву «ELISA kit» (компанія «Elabscience ${ }^{\circledR} »$, Китай).

Період спостереження за хворими становив 2 роки. Протягом цього періоду оцінювали перебіг $\mathrm{CH}$, ураховували розвиток пароксизмів фібриляції передсердь, частоту госпіталізацій із приводу декомпенсації захворювання.

Аналіз нормальності розподілу показників проводили за допомогою критерію ШапіроУїлка. 3 урахуванням тих обставин, що всі дані не підпорядковувались закону нормального розподілу, дані подано у вигляді медіани й інтерквартильного діапазону. Кількісні показники порівнювали за допомогою непарного T-тесту або непараметричного критерію Манна-Уїтні. Різницю серед частот ознак у групах оцінювали за критерієм $\chi^{2}$ Пірсона (із поправкою Йейтса при числі ознак меншому за 10). Для визначення прогностичного рівня $\mathrm{T}_{3 \mathrm{~B}}$ виконано ROC-аналіз. Проводили парне порівняння параметрів ROC-аналізу для різних показників. Розраховували відносний ризик із $95 \%$ довірчим інтервалом (ДІ). Для визначення зв'язку між показниками проводили кореляційний аналіз Спірмана (із урахуванням виду розподілу рівня $\mathrm{T}_{3 \mathrm{r}}$ ). 3 метою побудови моделі ризику госпіталізації проводили автоматичний регресійний аналіз. Різницю між значеннями вважали статистично вірогідною при рівні критерію значущості $\mathrm{p}<0,05$.

Статистичний аналіз проведено за допомогою пакетів програм IBM ${ }^{\circledR}$ SPSS $^{\circledR}$ Statistics, 20.0 та MedCalc, 16.4 (free version).

\section{Результати дослідження}

Під час проведення ROC-аналізу встановлено, що ризик розвитку повторної госпіталізації хворих на СН із приводу декомпенсації захворювання зростає за перевищення оптимальної точки поділу для сироваткового рівня $\mathrm{T}_{3 \mathrm{~B}} \leq 2,07$ пмоль/л (площа під кривою - 0,670; $95 \%$ ДІ - 0,564-0,776; чутливість - 67,44 \%; специфічність $-71,05 \%$; $p=0,0017)$. За даними статистичного аналізу, відносний ризик повторної госпіталізації хворих із $\mathrm{CH}$ протягом 2 років при рівні $\mathrm{T}_{3 \mathrm{~B}} \leq 2,07$ пмоль/л становить $2,224[1,363-3,630](\mathrm{p}<0,05)$.

У пацієнтів контрольної групи частота зустрічальності рівня $\mathrm{T}_{3 \mathrm{~B}} \leq 2,07$ пмоль/л достовірно не відрізнялась від такої при СН і дорівнювала 17,6 \% (3 із 17 хворих) проти 17,8 \% (28 із 157 хворих). 
Сумарно група хворих із $\mathrm{CH}$ не відрізнялась

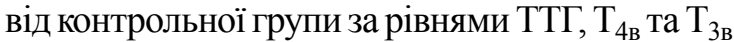
(табл. 1). У той самий час у пацієнтів із $\mathrm{CH}$ рівень $\mathrm{T}_{3 \mathrm{r}}$ був нижче $(280,65[213,00-285,85]$ пг/ мл), ніж у обстежених контрольної групи (411,09 [335,73-445,66] пг/мл), на 31,7\% $(\mathrm{p}<0,001)$.

Хворі на СН із повторною госпіталізацією протягом 2 років порівняно 3 пацієнтами зі сприятливим перебігом патології мали нижчі рівні $\mathrm{T}_{3 \mathrm{~B}}(1,90[1,57-2,30]$ пмоль/л проти 3,44 $[2,86-3,75]$ пмоль/л) - на 44,7 \% $(\mathrm{p}=0,001)$ та $\mathrm{T}_{3 \mathrm{r}}(239,10[173,37-361,11]$ пг/мл проти 293,67 [219,19-365,65] пг/мл) - на 18,6 \% (p=0,038), табл. 2. За рівнями $\mathrm{T}_{4 \mathrm{~B}}$ та ТТГ групи хворих не розрізнялись. $\mathrm{p}=0,001)$, рівень холестерину ліпопротеїдів низької щільності $(\alpha=0,116 ; \mathrm{p}=0,002)$, рівень загального холестерину $(\alpha=-0,072 ; \mathrm{p}=0,002)$, відносний вміст гранулоцитів у крові $(\alpha=-0,007$; $\mathrm{p}=0,017)$, концентрація $\mathrm{T}_{4 \mathrm{~B}}(\alpha=0,013 ; \mathrm{p}=0,026)$ (табл. 3).

Таким чином, ризик повторної госпіталізації протягом 2 років у хворих із $\mathrm{CH}$ можна описати таким рівнянням:

Ризик госпіталізаиії $(2$ роки $)=4,540+$ $0,009 \times$ маса тіла $-0,122 \times T_{3 в}+0,340$ (нетоксичний зоб) $-0,018 \times$ зріст $+0,116$ $\times$ ХС ЛПНЩ $-0,072 \times X C-0,007 \times$ гранулочити крові $+0,013 \times T_{46}$.

Таблиия 1. Сироваткові концентрації тиреоїдних гормонів і ТТГ у хворих із СН порівняно з показниками осіб контрольної групи

\begin{tabular}{|c|c|c|c|}
\hline Показник & Контрольна група $(n=17)$ & Хворі з $\mathrm{CH}(n=157)$ & $\mathrm{p}$ \\
\hline ТТГ, мМО/л & $1,54[0,82-2,074]$ & $1,81[1,13-2,85]$ & $>0,05$ \\
\hline 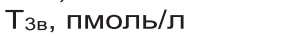 & $3,01[1,90-3,68]$ & $3,28[2,51-3,73]$ & $>0,05$ \\
\hline $\mathrm{T}_{4 в}$, пмоль/л & $11,90[7,56-13,93]$ & $12,12[8,90-14,63]$ & $>0,05$ \\
\hline 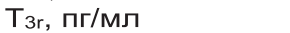 & $411,09[335,73-445,66]$ & $280,65[213,00-285,85]$ & $<0,001$ \\
\hline
\end{tabular}

Таблиия 2. Сироваткові концентрації тиреоїдних гормонів і ТТГ у хворих із СН

\begin{tabular}{|c|c|c|c|}
\hline \multirow[b]{2}{*}{ Показник } & \multicolumn{2}{|c|}{ Групи хворих із $\mathrm{CH}(\mathrm{n}=157)$} & \multirow[b]{2}{*}{$\mathrm{p}$} \\
\hline & $\begin{array}{c}\text { без повторної госпіталізації } \\
(n=114)\end{array}$ & $\begin{array}{c}\text { із повторною госпіталізацією } \\
(n=43)\end{array}$ & \\
\hline 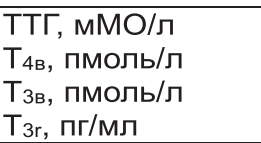 & $\begin{array}{l}1,88[1,22-2,79] \\
11,96[8,58-14,61] \\
3,44[2,86-3,75] \\
293,67[219,19-365,65]\end{array}$ & $\begin{array}{l}1,51[1,02-2,97] \\
12,59[9,86-15,30] \\
1,90[1,57-2,30] \\
239,10[173,37-361,11]\end{array}$ & $\begin{array}{l}>0,05 \\
>0,05 \\
=0,001 \\
=0,038\end{array}$ \\
\hline
\end{tabular}

За допомогою автоматичного регресійного аналізу була побудована модель повторної госпіталізації пацієнтів із СН у зв'язку з декомпенсацією захворювання протягом 2 років. Статистичною програмою з усіх 44 показників було відібрано 8 змінних для моделі: маса тіла $(\alpha=0,009 ; \mathrm{p}=0,0001)$, рівень $\mathrm{T}_{3 \text { в }}(\alpha=-0,122$; $\mathrm{p}=0,0001)$, наявність нетоксичного зобу $(\alpha=0,340$;
Ризик розвитку повторної госпіталізації хворих із СН у зв'язку з декомпенсацією захворювання, згідно з даними ROC-аналізу, зростає за перевищення оптимальної точки поділу для значення рівняння регресійної моделі $\geq 1,321$ ум. од. (площа під кривою - 0,714; $95 \%$ ДІ - 0,600-0,773; чутливість - 93,78 \%; специфічність $-40,45 \%$; $\mathrm{p}=0,0001)$.

Таблиия 3. Параметри автоматичної регресійної моделі повторної госпіталізації пацієнтів із $\mathrm{CH}$

\begin{tabular}{|c|c|c|c|c|c|}
\hline \multirow{2}{*}{ Показник } & \multirow{2}{*}{$\alpha$} & \multicolumn{2}{|c|}{95 \% ДІ для $\alpha$} & \multirow{2}{*}{$F$} & \multirow{2}{*}{$p$} \\
\hline & & нижній & верхній & & \\
\hline Маса тіла & 0,009 & 0,005 & 0,013 & 18,382 & $=0,0001$ \\
\hline $\mathrm{T}_{3 \mathrm{~B}}$ & $-0,122$ & $-0,185$ & $-0,059$ & 14,530 & $=0,0001$ \\
\hline Нетоксичний зоб & 0,340 & 0,530 & 0,150 & 12,422 & $=0,001$ \\
\hline Зріст & $-0,018$ & $-0,029$ & $-0,008$ & 11,712 & $=0,001$ \\
\hline ХС ЛПНЩ & 0,116 & 0,042 & 0,190 & 9,449 & $=0,002$ \\
\hline Загальний XC & $-0,072$ & $-0,119$ & $-0,026$ & 9,419 & $=0,002$ \\
\hline Гранулоцити & $-0,007$ & $-0,012$ & $-0,001$ & 5,765 & $=0,017$ \\
\hline $\mathrm{T}_{4 \mathrm{~B}}$ & 0,013 & 0,002 & 0,024 & 5,006 & $=0,026$ \\
\hline
\end{tabular}

Статистична характеристика моделі: $F=10,549 ; p<0,0001 ; C=4,540$ 
Iз сироватковою концентрацією $\mathrm{T}_{3 \mathrm{~B}}$ мають негативну кореляційну залежність рівень лімфоцитів крові $(\mathrm{r}=-0,209 ; \mathrm{p}=0,015)$, функціональний клас стенокардії напруження (r=-0,259; $\mathrm{p}=0,001)$, наявність коронарної інтервенції в анамнезі $(\mathrm{r}=-0,283 ; \mathrm{p}=0,0001)$, імовірність повторної госпіталізації протягом 2 років $(\mathrm{r}=-0,262 ; \mathrm{p}=0,001)$; позитивну - рівень креатиніну крові $(\mathrm{r}=0,181$; $\mathrm{p}=0,040)$.

Обговорення результатів досліджень

Оптимальні концентрації гормонів щитоподібної залози необхідні для нормального функціонування серцево-судинної системи; їхній надлишок або дефіцит справляють дезінтегруючу дію. Трийодтиронін чинить позитивну інотропну й хронотропну дії на міокард, регулюючи транскрипцію міозит-специфічних генів [8], безпосередньо впливає на гладеньку мускулатуру судин, сприяючи дилатації артеріол і зниженню периферичної судинної резистентності.

Зниження сироваткової концентрації $\mathrm{T}_{3}$ та паралельне підвищення вмісту $\mathrm{T}_{3 \mathrm{r}} \in$ загальним результатом багатьох захворювань, наприклад, травм, голоду та післяопераційного стану. Ці зміни функції осі «гіпоталамус-гіпофіз-щитоподібна залоза» називаються синдромом «низького» трийодтироніну. Передбачається, що даний стан може бути адаптивним компенсаторним механізмом для збереження споживання енергії та величина зміни концентрації $\mathrm{T}_{3}$ варіює залежно від тяжкості захворювання [9].

У [10-12] критерієм визначення синдрому «низького» трийодтироніну є нижня межа норми $\mathrm{T}_{3 в}(\leq 2,5$ пмоль/л) за нормальних рівнів $\mathrm{T}_{4 \mathrm{~B}}$ i ТТГ. У нашому дослідженні виявлено, що більш значущим для хворих із $\mathrm{CH} \epsilon$ рівень $\mathrm{T}_{3 \mathrm{~B}} \leq 2,07$ пмоль/л.

Синдром «низького» трийодтироніну - найпоширеніша зміна метаболізму гормонів щитоподібної залози за СН, що зустрічається приблизно у третини пацієнтів [13]. У нашому дослідженні частота зниження сироваткового рівня $\mathrm{T}_{3 \mathrm{~B}} \leq 2,07$ пмоль/л у хворих із СН при госпіталізації становить $17,2 \%$.
Після інфаркту міокарда, кардіохірургічних інтервенцій та при зупинці серця, а такожпри СН знижується концентрація $\mathrm{T}_{3}$ у сироватці крові. При хронічних захворюваниях, таких як $\mathrm{CH}$, низька концентрація $\mathrm{T}_{3}$ може викликати негативні наслідки. Навіть пацієнти з СН I функціонального класу і на стадії компенсації мають деякі ранні прояви синдрому «низького» трийодтироніну [13]. Відомо [14], що в пацієнтів із СН даний синдром асоціюється з поганою функцією ЛШ, тахіаритмією та підвищенням смертності.

\section{Висновки}

1. У зв'язку з тим що зниження сироваткового рівня трийодтироніну впливає на перебіг серцевої недостатності, можна вважати доцільним використання його значення $\leq 2,07$ пмоль/л як предиктора несприятливого перебігу захворювання.

2. У регресійну модель повторної госпіталізації пацієнтів із серцевою недостатністю входять такі показники: маса, концентрації тироксину і трийодтироніну в сироватці крові, наявність нетоксичного зобу, зріст, рівні загального холестерину й холестерину ліпопротеїдів низької щільності та відносний вміст гранулоцитів крові.

3. Ризик розвитку повторної госпіталізації хворих із серцевою недостатністю 3 приводу декомпенсації захворювання зростає за перевищення значення рівняння регресійної моделі $\geq 1,321$ ум. од. (чутливість - 93,78 \% та специфічність $-40,45 \%, \mathrm{p}=0,0001)$.

\section{Перспективність дослідження}

Обмеженість дослідження невеликою кількістю хворих і малим періодом спостереження зменшує силу статистичних даних. Результати подальших досліджень, імовірно, дозволять більш точно стратифікувати групи пацієнтів із несприятливим перебігом серцевої недостатності й оптимізувати індивідуальну терапевтичну програму.

Участь авторів: Пивовар С.М. - концепція й дизайн дослідження, збирання, аналіз та інтерпретація даних, написання статті.

Конфлікт інтересів: відсутній.

\section{Список літератури}

1. Altered thyroid hormone metabolism in advanced heart failure / M. A. Hamilton, L. W. Stevenson, M. Luu, J. A. Walden // J. Am. Coll. Cardiol. - 1990. - Vol. 16 (1). - P. 91-95.

2. Relation between free triiodothyronine / free thyroxine ratio, echocardiographic parameters and mortality in dilated cardiomyopathy / G. Kozdag, D. Ural, A. Vural [et al.] // Eur. J. Heart Fail. - Vol. 7 (1). - P. 113-118. 
3. Sick euthyroid syndrome in patients with moderate-to-severe chronic heart failure / C. Opasich, F. Pacini, N. Ambrosino [et al.] // Eur. Heart J. - 1996. - Vol. 17 (12). - P. 1860-1866.

4. Prognostic value of combined measurement of brain natriuretic peptide and triiodothyronine in heart failure / C. Passino, A. Pingitore, P. Landi [et al.] // J. Card. Fail. - 2009. - Vol. 15 (1). - P. 35-40. DOI : $10.1016 /$ j.cardfail.2008.08.008.

5. Triiodothyronine levels for risk stratification of patients with chronic heart failure / A. Pingitore, P. Landi, M. C. Taddei [et al.] // Am. J. Med. - Vol. 118. - P. 132-136. - DOI : 10.1016/j.amjmed.2004.07.052.

6. Рудик Ю. С. Кардиопротективные механизмы гормонов щитовидной железы / Ю. С. Рудик, С. Н. Пивовар, О. М. Билецкая // Український терапевтичний журнал. - 2013. - № 3. - С. 95-102.

7. ESC Guidelines for the diagnosis and treatment of acute and chronic heart failure 2016. The Task Force for the diagnosis and treatment of acute and chronic heart failure of the European Society of Cardiology (ESC) developed with the special contribution of the Heart Failure Association (HFA) of the ESC / P. Ponikowski, A. A. Voors, S. D. Anker [et al.] // European Heart Journal. - 2016. - Vol. 37 (27). P. 2129-2200. - DOI : 10.1093/eurheartj/ehw128.

8. Usefulness of serum triiodothyronine (T3) to predict outcomes in patients hospitalized with acute heart failure / G. D. Rothberger, S. Gadhvi, N. Michelakis [et al.] // Am. J. Cardiol. - 2017. - Vol. 119 (4). - P. 599-603. - DOI : 10.1016/j.

9. Low fT3 is associated with diminished health-related quality of life in patients with acute coronary syndrome treated with drug-eluting stent: a longitudinal observational study / C. Xue, L. Bian, Y. S. Xie [et al.] // Oncotarget. - 2017. - Vol. 8 (55). - P. 94580-94590. - DOI : 10.18632/oncotarget.21811.

10. Danzi S. Thyroid disease and the cardiovascular system / S. Danzi, I. Klein // Endocrinol. Metab. Clin. North Am. - 2014. - Vol. 43. - P. 517-528. - DOI : 10.1089/105072502760143836.

11. Gerdes A. M. Thyroid hormone and cardioprotection / A. M. Gerdes, K. Ojamaa // Compr. Physiol. - 2016. - Vol. 6 (3). - P. 1199-1219. - DOI : 10.1002/ cphy.c150012.

12. Subclinical hypothyroidism is an independent predictor of adverse cardiovascular outcomes in patients with acute decompensated heart failure / Tomohiro Hayashi, Takuya Hasegawa, Hideaki Kanzaki [et al.] // ESC Heart Fail. - 2016. - Vol. 3 (3). - P. 168-176. - DOI : 10.1002/ehf2.12084.

13. Low T3 syndrome is a strong prognostic predictor in diffuse large B cell lymphoma / R. Gao, J.-H. Liang, L. Wang [et al.] // British Journal of Haematology. - 2017. - Vol. 177 (1). - P. 95-105. DOI : $10.1111 /$ bjh. 14528 .

14. Shanoudy H. Early manifestations of «sick euthyroid» syndrome in patients with compensated chronic heart failure / H. Shanoudy, A. Soliman, S. Moe // J. Card. Fail. - 2001. - Vol. 7 (2). - P. 146152. - DOI : 10.1054/jcaf.2001.24665.

\section{References}

1. Hamilton M.A., Stevenson L.W., Luu M., Walden J.A. (1990). Altered thyroid hormone metabolism in advanced heart failure. J. Am. Coll. Cardiol., vol. 16 (1), pp. 91-95.

2. Kozdag G., Ural D., Vural A., Agacdiken A., Kahraman G., Sahin T. et al. (2005). Relation between free triiodothyronine / free thyroxine ratio, echocardiographic parameters and mortality in dilated cardiomyopathy. Eur. J. Heart Fail., vol. 7 (1), pp. 113-118.

3. Opasich C., Pacini F., Ambrosino N., Riccardi P.G., Febo O., Ferrari R. et al. (1996). Sick euthyroid syndrome in patients with moderate-to-severe chronic heart failure. Eur. Heart J., vol. 17 (12), pp. 18601866.

4. Passino C., Pingitore A., Landi P., Fontana M., Zyw L., Clerico A. et al. (2009). Prognostic value of combined measurement of brain natriuretic peptide and triiodothyronine in heart failure. J. Card. Fail., vol. 15 (1), pp. 35-40, DOI 10.1016/j.cardfail.2008.08.008.

5. Pingitore A., Landi P., Taddei M.C., Ripoli A., L’Abbate A., Iervasi G. (2005). Triiodothyronine levels for risk stratification of patients with chronic heart failure. Am. J. Med., vol. 118, pp. 132-136, DOI 10.1016/j.amjmed.2004.07.052.

6. Rudik Yu.S., Pivovar S.N., Biletskaia O.M. (2013). Kardioprotektivnyie mekhanizmy hormonov shchitovidnoi zhelezy [Cardioprotective mechanisms of thyroid hormones]. Ukrainskyi terapevtychnyi zhurnal - Ukrainian Therapeutic Journal, № 3, pp. 95-102 [in Russian]. 
7. Ponikowski P., Voors A.A., Anker S.D., Bueno H., Cleland J.G.F., Coats A.J.S. et al. (2016). ESC Guidelines for the diagnosis and treatment of acute and chronic heart failure 2016. The Task Force for the diagnosis and treatment of acute and chronic heart failure of the European Society of Cardiology (ESC) developed with the special contribution of the Heart Failure Association (HFA) of the ESC. European Heart J., vol. 37 (27), pp. 2129-2200, DOI 10.1093/eurheartj/ehw128.

8. Rothberger G.D., Gadhvi S., Michelakis N., Kumar A., Calixte R., Shapiro L.E. (2017). Usefulness of serum triiodothyronine (T3) to predict outcomes in patients hospitalized with acute heart failure. Am. J. Cardiol., vol. 119 (4), pp. 599-603, DOI 10.1016/j.

9. Xue C., Bian L., Xie Y.S., Yin Z.F., Xu Z.J., Chen Q.Z. et al. (2017). Low fT3 is associated with diminished health-related quality of life in patients with acute coronary syndrome treated with drugeluting stent: a longitudinal observational study. Oncotarget, vol. 8 (55), pp. 94580-94590, DOI 10.18632/ oncotarget.21811.

10. Danzi S., Klein I. (2014). Thyroid disease and the cardiovascular system. Endocrinol. Metab. Clin. North Am., vol. 43, pp. 517-528, DOI 10.1089/105072502760143836.

11. Gerdes A.M., Ojamaa K. (2016). Thyroid hormone and cardioprotection. Compr. Physiol., vol. 6 (3), pp. 1199-1219, DOI 10.1002/cphy.c150012.

12. Tomohiro Hayashi, Takuya Hasegawa, Hideaki Kanzaki, Akira Funada, Makoto Amaki, Hiroyuki Takahama et al. (2016). Subclinical hypothyroidism is an independent predictor of adverse cardiovascular outcomes in patients with acute decompensated heart failure. ESC Heart Fail., vol. 3 (3), pp. 168-176, DOI 10.1002/ehf2.12084.

13. Gao R., Liang J.-H., Wang L., Zhu H.Y., Wu W., Wu J.Z. et al. (2017). Low T3 syndrome is a strong prognostic predictor in diffuse large B cell lymphoma. British Journal of Haematology, vol. 177 (1), pp. 95-105, DOI 10.1111/bjh.14528.

14. Shanoudy H., Soliman A., Moe S. (2001). Early manifestations of «sick euthyroid» syndrome in patients with compensated chronic heart failure. J. Card. Fail., vol. 7 (2), pp. 146-152, DOI 10.1054/ jcaf.2001.24665.

\section{С.Н. Пивовар}

\section{МОДЕЛЬ НЕБЛАГОПРИЯТНОГО ТЕЧЕНИЯ СЕРДЕЧНОЙ НЕДОСТАТОЧНОСТИ С УЧЕТОМ ТИРЕОИДНОГО СТАТУСА БОЛЬНЫХ}

Обследовано 157 пациентов с сердечной недостаточностью $(\mathrm{CH})$ - перенесенным инфарктом миокарда, у которых определяли предикторы неблагоприятного течения заболевания в зависимости от тиреоидного статуса. При госпитализации проведена стандартизированная оценка состояния, определены показатели внутрисердечной гемодинамики, клинического и биохимического анализов крови, уровни гормонов щитовидной железы. Установлено, что риск повторной госпитализации больных СН по поводу декомпенсации заболевания возрастает при превышении оптимальной точки разделения для сывороточного уровня свободного трийодтиронина $\leq 2,07$ пмоль/л. Относительный риск повторной госпитализации больных с $\mathrm{CH}$ в течение 2 лет при уровне свободного трийодтиронина $\leq 2,07$ пмоль/л составляет $2,224[1,363-3,630](\mathrm{p}<0,05)$. С помощью автоматического регрессионного анализа построена модель повторной госпитализации пациентов с СН по поводу декомпенсации заболевания в течение 2 лет. В нее вошли следующие показатели: масса тела, уровень свободного трийодтиронина, наличие нетоксического зоба, уровни холестерина липопротеидов низкой плотности и общего холестерина, относительное содержание гранулоцитов в крови, концентрация свободного тироксина. По данным ROC-анализа, риск развития повторной госпитализации больных с СН по поводу декомпенсации заболевания возрастает при превышении оптимальной точки разделения для значения уравнения регрессионной модели $\geq 1,321$ усл. ед. В связи с тем что снижение сывороточного уровня трийодтиронина влияет на течение $\mathrm{CH}$, можно предположить целесообразным использование его значения $\leq 2,07$ пмоль/л как предиктора неблагоприятного течения заболевания.

Ключевые слова: сердечная недостаточность, трийодтиронин, тироксин, течение заболевания, регрессионная модель. 


\section{S.M. Pyvovar \\ THE MODEL OF HEART FAILURE ADVERSE COURSE WITH ACCOUNT OF THE THYROID STATUS OF PATIENTS}

We examined 157 patients with heart failure (HF) - myocardial infarction, in which predictors of an unfavorable course of the disease were determined depending on thyroid status. During hospitalization, a standardized assessment of the condition was carried out, indicators of intracardiac hemodynamics, clinical and biochemical blood tests, and levels of thyroid hormones were determined. It was established that the risk of re-hospitalization of patients with heart failure due to decompensation of the disease increases when the optimal separation point is exceeded for serum free triiodothyronine level $\leq 2,07 \mathrm{pmol} / 1$. The relative risk of re-hospitalization of patients with heart failure within 2 years at a level of free triiodothyronine $\leq 2,07 \mathrm{pmol} / 1$ is $2,224[1,333-3,630](\mathrm{p}<0,05)$. Using automatic regression analysis, a model for re-hospitalization of patients with heart failure due to decompensation of the disease for 2 years was built. It included the following indicators: body weight, the level of free triiodothyronine, the presence of non-toxic goiter, cholesterol levels of low density lipoproteins and total cholesterol, the relative content of granulocytes in the blood, the concentration of free thyroxine. According to the ROC analysis, the risk of re-hospitalization of patients with heart failure due to decompensation of the disease increases when the optimal separation point is exceeded for the value of the regression model equation $\geq 1,321$ conv. units. Due to the fact that a decrease in the serum level of triiodothyronine affects the course of HF, we can assume that it is advisable to use its value $\leq 2,07 \mathrm{pmol} / 1$ as a predictor of the adverse course of the disease.

Keywords: heart failure, triiodothyronine, thyroxin, course of the disease, regression model.

Надійшла 15.03.19

\section{Відомості про автора}

Пивовар Сергій Миколайович - кандидат медичних наук, старший науковий співробітник відділу клінічної фармакології та фармакогенетики неінфекційних захворювань ДУ «Національний інститут терапії ім. Л.Т. Малої НАМН України».

Адреса: 61039, м. Харків, пр. Л. Малої, 2а, ДУ «Національний інститут терапії ім. Л.Т. Малої НАМН України».

Тел.: +38(057)373-90-90.

E-mail: sn_p@ukr.net.

ORCID: https://orcid.org/0000-0002-9991-8027. 